\title{
KOHESI DAN KOHERENSI WACANA STAND UP COMEDY PRANCIS DAN INDONESIA
}

\author{
Esa Agita Anjani \\ Fakultas Ilmu Budaya Universitas Gajdah Mada \\ Email: esa.agita@gmail.com
}

\begin{abstract}
Stand up comedy is an art comedy show which develops rapidly in all over world nowadays. Stand up comedy considered as a smart comedy. This research will concern about french and indonesian stand up comedy discourse by Tomer Sisley (french) and Raditya Dika (indonesian). This paper focus on cohesion and coherence analysis. The results showed that cohesion and coherence are the most important aspect for making a good stand up comedy discourse. Cohesion aspect in stand up comedy are gramatical cohesion (reference, substitution, ellipsis, conjunction) and lexical cohesion (repetion, synonim, antonym, collocation). Also, coherence aspects are additional relation, temporal relation, oppositional relation, affectional relation, causal relation, conditional relation. Repetion is a cohesive tools which more dominate in this stand up comedy discourse.
\end{abstract}

Keywords: Stand up comedy, Discourse, Cohesion, Coherence

\begin{abstract}
ABSTRAK
Stand up comedy merupakan sebuah seni pertunjukan komedi yang sedang marak berkembang saat ini di berbagai negara. Stand up comedy dianggap sebagai komedi yang mampu menampilkan sebuah lelucon yang cerdas. Penelitian ini akan mengkaji wacana stand up comedy Prancis (oleh Tomer Sisley) dan Indonesia (oleh Raditya Dika) yang dilihat dari aspek kohesi dan koherensi. Hasil dari penelitian ini menunjukkan bahwa aspek kohesi dan koherensi sangat mendukung dalam membangun sebuah keutuhan wacana stand up comedy. Aspek kohesi yang ada dalam wacana Stand up comedy mencakup kohesi gramatikal (referesnsi, substitusi, elipsis, dan konjungsi) dan kohesi leksikal (repetisi, sinonimi, antonimi, kolokasi). Adapun aspek koherensi dalam wacana antara lain hubungan makna penambahan, hubungan makna kewaktuan, hubungan makna pertentangan, hubungan makna sebab, hubungan makna akibat, hubungan persyaratan, dan pengandaian. Adapun kohesi leksikal repetisi/perulangan merupakan piranti kohesi yang paling mendominasi.
\end{abstract}

Kata Kunci: Stand up comedy, Wacana, Kohesi, Koherensi 


\section{PENGANTAR}

Stand up comedy merupakan sebuah bentuk pertunjukan seni komedi yang dibawakan secara monolog oleh seorang comic. Comic adalah seseorang yang hidup menjadi lucu lewat menceritakan lelucon (Ramon Papana, 2012). Secara langsung berbicara di depan. Stand up comedy merupakan label baru dalam seni melawak, khususnya seni lawak monolog. Jauh sebelum orang-orang mengenal stand up comedy yang ada seperti sekarang ini, ada seni lawak tunggal yang sudah berkembang, misalnya komedi tunggal yang dibawakan oleh Charlie Chaplin dan Basiyo. Komedi tunggal dikenal sebagai stand up comedy sesungguhnya baru dimulai pada tahun 1966 yang dikemukakan oleh orang-orang dari Oxford, Inggris.

Saat ini stand up comedy telah menjamur di berbagai negara, seperti Prancis dan Indonesia. Jamel Débouzze merupakan tokoh yang memperkenalkan stand up comedy di Prancis dengan mendirikan Jamel Comedy Club. Di dalam Jamel Comedy Club terdapat sejumlah comic ternama seperti Gad Elmaleh, Tomer Sisley. Di Indonesia, komedi tunggal dengan kemasan stand up comedy pertama kali diperkenalkan oleh Ramon Papana. Ia memperjuangkan stand up comedy di Indonesia sejak tahun 1997 hingga akhirnya pada tahun 2011 stand up comedy berkembang pesat dan lahirlah comic-comic berbakat seperti Raditya Dika, Abdel, Ryan, dan sebagainya.

Kelucuan-kelucuan yang hadir dalam lawakan stand up comedy biasanya bermula dari comic yang mencela dirinya sendiri atau bahkan mencela orang lain. Tidak hanya itu, stand up comedy juga mengangkat topik dari fenomena-fenomena sosial zaman sekarang yang dikemas secara humoris. Masalah kegalauan remaja zaman sekarang dan masalah percintaan adalah lawakan yang kerap dibawakan oleh Raditya Dika.

Pembawaan stand up comedy yang dilakukan secara monolog, membuat para comic harus mempersiapkan materi lawakan terlebih dahulu agar materi lawakan mereka utuh dan memiliki kesinambungan. Untuk itu, menstrukturasi sebuah lawakan harus memperhatikan aspek-aspek kohesi agar terbentuk suatu materi lawakan yang koheren. Aspek kohesif merupakan aspek yang berkenaan dengan hubungan bentuk antara bagian-bagian dalam suatu wacana. Selanjutnya, aspek koherensif merupakan aspek yang menandai hubungan makna secara semantis antar-bagian wacana.

Kesuksesan comic dalam membawakan materi stand up comedy tidak hanya ditentukan dari keutuhan materi lawakan, dalam hal ini berupa sarana tekstualnya juga didukung dengan unsur di luar teks, yaitu berkenaan dengan unsur supra segmental. Unsur suprasegmental meliputi intonasi, tekanan, dan nada. Selain itu, mimik wajah dan gesture sangat berperan penting dalam membangun kelucuan penyajian stand up comedy.

\section{PEMBAHASAN KOHESI}

Pada wacana, kohesi diartikan sebagai kepaduan bentuk yang secara struktural membentuk ikatan sintaktikal dan berkenaan dengan hubungan bentuk antara bagianbagian dalam suatu wacana. Dengan kata lain, kohesi merupakan aspek fisik yang terdapat dalam suatu wacana. Widdowson (2007:46) mengungkapkan bahwa perangkat kohesi menghubungkan bagian-bagian wacana dalam satu kesatuan teks. Relasi kohesif sangat mendukung bagi pendengar/ penerima wacana dalam memahami sebuah wacana. Halliday dan Hasan (1976:6) membagi kohesi dalam dua jenis yaitu kohesi gramatikal dan kohesi leksikal.

\section{KOHESI GRAMATIKAL}

Kohesi gramatikal berkaitan dengan aspek gramatikal antarwacana. Kohesi gramatikal mencakup referensi, substitusi, elipsis, dan konjungsi. Pengertian referensi merupakan salah satu piranti kohesi gramatikal yang berupa jenis satuan lingual tertentu yang menunjuk satuan lingual yang mendahului atau mengikutinya. Pada wacana, referensi dibagi menjadi dua yaitu 
eksoforis (di luar teks) dan endoforis (di dalam teks). Referensi endoforis terbagi lagi dalam dua pola yaitu referensi anafora dan referensi katafora. Referensi anafora merupakan satuan lingual yang menunjuk pada jenis satuan lingual lain yang telah disebutkan sebelumnya, sedangkan referensi katafora merupakan satuan lingual yang mengacu atau menunjuk pada satuan lingual lain yang akan dijelaskan sesudahnya. Baik penunjukan anaforis maupun kataforis, ditunjukkan oleh kata-kata yang bersifat deiktis, yaitu kata yang referennya berpindah-pindah atau bergantiganti bergantung pada siapa yang menjadi si pembicara dan tergantung pada saat dan tempat dituturkannya kata itu (Kaswanti, Purwo 1984:1).

Referensi dibedakan menjadi tiga macam, yaitu (1) referensi persona, (2) referensi demonstratif, dan (3) referensi komparatif. Referensi persona direalisasikan melalui pronomina persona yang terdiri persona pertama (je/tu), kedua (tu/vous), dan ketiga baik tunggal (il/elle/on)maupun jamak (vous/ils/elles).

(1) t'sais j'ai peur de m'engager c'est un truc qui me flipper

('lo tau nggak sih, gue itu takut banget tunangan')

(2) elle m'a lancé un ultimatum ('dia ngasih gue ultimatum')

Dua wacana di atas mengandung referensi persona. Dalam wacana (1) referensi persona mengacu pada persona pertama dan kedua tunggal yaitu «je»' aku/gue' dan «tu» 'kamu/lo'. "Je» 'aku/gue'di sini mengacu pada si penutur/comic, sedangkan " tu "'kamu/lo'mengacu kepada lawan tutur/ penonton. Penggunaan «tu» 'kamu/lo' yaitu untuk menunjukkan keakraban dan lebih komunikatif. Pada wacana (2), referensi persona yang ada, yaitu persona ketiga tunggal femina «elle» 'dia (perempuan). «Elle» merupakan referensi persona yang merujuk pada seorang perempuan yang merupakan kekasih dari si penutur/comic.

Kemudian, pronom personel «me» merupakan referensi yang antesedennya yaitu «je» 'aku/gue' yang merupakan si penutur/comic itu sendiri. Kedua referensi tersebut bersifat anaforis karena antesedennya berada di sebelah kiri.Pada wacana (2) comic mengucapkan tuturan dengan nada yang tinggi dan menekankan pada kata «elle» 'dia (perempuan). Akan tetapi, pada wacana (1) nada tuturan melemah karena memiliki maksud bahwa si comic merasa takut untuk bertunangan dengan perempuan.

Perihal referensi persona juga ditemukan dalam wacana stand up comedy Indonesia, berikut analisisnya:

(3) Gue dateng ke sini dengan tujuan mencari pacar baru ya, mudah-mudahan dari penonton ada yang bisa jadi pacar gue pada malem hari ini." (SC Raditya Dika)

Terdapat referensi pronomina persona orang pertama tungggal yaitu gue yang mengacu pada penutur, kemudian terdapat pronomina posesif 'pacar gue'yang juga mengacu pada pronomina personal 'gue'.

Tuturan (3) merupakan tuturan yang bersifat deklaratif karena memiliki pola intonasi datar-turun.

(4) Yang cowok make tau ngga apa? She is my love, tanda panah ke kiri. Yang cewek di sebelah kirinya, He is my love, tanda panah ke kanan!

Pada wacana (4) terdapat enklitik -nya yang menunjuk pada frasa 'yang cowok' yang telah disebutkan sebelumnya. Enklitiknya ini merupakan referensi pronomina persona yang bersifat anaforis.

Pada wacana (4) kalimat 'yang cowok make tau ngga apa?' Memiliki pola intonasi datar-naik karena berupa kalimat interogatif dan terdapat penekanan pada frasa 'yang cowok'. Pada tuturan 'she is my love, tanda panah ke kiri' terdapat penekanan pada frasa tanda panah ke kiri. Hal ini dimaksudkan karena pasangan dari si cowo berada di sebelah kirinya. Kemudian pada tuturan selanjutnya 'yang cewek di sebelah kirinya, he is my love, tanda panah ke kanan' memiliki 
pola intonasi yang datar, tetapi memberi penekanan pada frasa tanda panah ke kanan sama seperti dengan wacana sebelumnya. Tuturan ini berarti pasangan dari si cewek berada di sebelah kanannya.

Referensi Demonstratif menurut Halliday (1976) menyatakan bahwa referensi demonstratif merupakan bentuk yang esensial dari sebuah verba penunjukan. Penutur mengidentifikasi sebuah referensi berdasarkan skala proksimitas (skala kedekatan). Adverbial demonstratif seperti di sini, di sana, sekarang, kemudian atau dalam bahasa Prancis ici, là, là-bas, maintenant merupakan referensi yang merujuk pada tempat dan waktu. Referensi adverbial ini merupakan sebuah pelengkap yang berfungsi sebagai modifikator.

(5) pour moi la vraie, la vraie vérité pour moi aujourd'hui c'est que j'ai 29 ans bientôt 34.(SC Tomer Sisley)

('Buat gue kebeneran itu, kebenaran yang hakiki buat gue itu sekarang umur gue 29 tahun hampir menuju 34')

Satuan lingual «bientôt» 'segera' merupakan sebuah penanda referensi adverbial yang menunjukkan keterangan waktu. Kata «bientôt» 'segera' berfungsi sebagai modifikator dalam struktur kalimat tersebut. Tuturan (5) memiliki intonasi yang datar disertai jeda pada klausa «pour moi la vraie» 'kebenaran yang hakiki buat gue'.

Pada bahasa Indonesia, referensi pronomina demosntratif yaitu ini dan itu. Ini mengacu pada referen yang dekat dengan pembicara dan merupakan pengacuan kataforis, sedangkan itu mengacu pada referen yang agak jauh dari pembicara dan merupakan pengacuan anaforis.

(5) Mudah-mudahan dari penonton ada yang bisa jadi pacar gue pada malem hari ini. Itu kenapa laki-laki senyum banget ya di situ ya heeh!!

(RD)

Satuan lingual 'itu'merupakan penanda referensi pronomina demonstratif yang bersifat anaforis. Acuan dari kata 'itu'adalah kata 'penonton'yang letaknya ada di kalimat sebelumnya.Wacana di atas memiliki pola intonasi datar-tinggi pada tuturan 'Itu kenapa laki-laki senyum banget ya di situ ya heeh'

Referensi demonstratif nomina dalam bahasa Prancis berperan sebagai determinan yang digunakan untuk menunjuk suatu objek baik makhluk hidup maupun benda atau disebut juga sebagai desiksis (Dubois, 1973:63). Struktur referensi demonstratif nomina dalam bahasa Prancis terletak sebelum kata benda dan bentuknya dapat berubah sesuai gender dan jumlah.

\begin{tabular}{|c|c|c|}
\hline Maskulin tunggal & $\begin{array}{l}\text { Femina } \\
\text { tunggal }\end{array}$ & Jamak \\
\hline $\mathrm{Ce}(\mathrm{ci} / \mathrm{là})$ & Cette (ci/là) & Ces (ci-là) \\
\hline
\end{tabular}

(7) je commence un petit peu à regretter parce que...parce que... parce que voilà elle je pensais vraiment que c'était la femme de ma vie, vraiment j'étais fou amoureux de cette fille-là.

('gue sedikit nyesel sih soalnya... soalnya... soalnya dia, gue berpikir bahwa dia emang perempuan dalam hidup gue gitu, gue jatuh banget sama cewe itu')

Wacana (7) terdapat frasa yang mengandung nomina yaitu " cette fille-là » 'cewe itu' yang referennya mengacu pada klausa sebelumnya yaitu «la femme de ma vie» 'perempuan dalam hidup gue'. Penggunaan satuan lingual «-là »setelah nomina bahwa nomina yang disebutkan atau dituturkan berada jauh dari penutur.

Pada wacana (7) intonasinya datar dan terdapat jeda antarfrase ketika penutur mengucapkan kata parce que. Di dalam wacana tersebut juga terjadi penekanan pada frasa « cette fille-là »' cewe itu'.

Referensi komparatif adalah salah satu jenis kohesi gramatikal yang membandingkan dua hal atau lebih yang mempunyai kemiripan ataupun perbedaan. Referensi komparatif ditunjukkan melalui penggunaan kategori adjektiva dan adverbia. 
(8) Tu me quittes pour une fille plus jeune que moi et plus belle que moi.

('kamu ninggalin aku buat cewek yang lebih muda dari aku dan lebih cantik dari $\mathrm{aku} \mathrm{u}^{\prime}$

Pada konteks wacana (8) adalah unsur lingual «jeune» 'muda'. «Plus jeune» 'lebih muda' digunakan untuk memperjelas klausa yang disebutkan sebelumnya, yaitu " tu me quittes pour une fille plus jeune " 'lo ninggalin gue buat cewe yang lebih muda' yang dibandingkan dengan unsur lingual setelahnya, yaitu «que moi» 'dari gue'.

(9) Tidak punya toleransi dalam berasmara. Kasian orang-orang kayakgue

Referensikomparatifdalamwacana stand up comedy di atas ditandai dengan adanya satuan lingual 'kayak' (dalam bahasa formal, seperti). Hal ini penutur membandingkan dirinya yang jomblo dengan para jomblo lainnya yang merasa sakit hati jika melihat ada orang yang berpacaran.

Pola tuturan 'tidak punya toleransi dalam berasmara' yaitu datar-tinggi sedangkan tuturan berikutnya kasian orang-orang kayak gue memiliki pola intonasi yang datarturun/cenderung melemah.

\section{Substitusi/Penggantian}

Substitusi merupakan penggantian konstituen tertentu dengan konstituen lain (Baryadi 2002:21). Kohesi substitusi terdiri dari dua unsur, yaitu unsur terganti dan unsur pengganti. Substitusi dan referensi mungkin terlihathampir sama, tetapi terdapat perbedaan yang konkret antara substitusi dan referensi. Substitusi merupakan sebuah relasi gramatikal misalnya kata atau frasa, sedangkan referensi merupakan hubungan makna. Pada sistematika linguistik, referensi masuk dalam tataran semantik sedangkan substitusi masuk dalam tataran leksiko gramatikal. Proses substitusi terdapat unsur pengganti dan unsur terganti, dengan demikian unsur terganti memiliki fungsi yang sama dengan unsur pengganti.
(10) En règle générale la plupart des filles, elles veulent, elles veulent elles veulent du sérieux tout de suite euh"

('Biasanya, kebanyakan cewek itu, mereka pengen cepet-cepet serius euh')

Pada wacana (10) terjadi proses substitusi yaitu «la plupart des filles» 'kebanyakan cewe' pada klausa pertama disubstitusi dengan elles. Elles memiliki fungsi yang sama dengan frasa «la plupart des filles»'kebanyakan cewe'.

Pada wacana di atas, intonasi pada tuturan «en règle générale la plupart des filles, elles veulent» 'biasanya, kebanyakan cewe itu, mereka pengen' merupakan intonasi yang datar.

(11) gua ngliat orang pacaran pake couple T-Shirt itu geli banget!! Hoeeekkkk Itu geli banget tau nggak yang cowok make tau ngga apa? She is my love tanda panah ke kiri yang cewek di sebelah kirinya He is my love tanda panah ke kanan!!

Pada wacana di atas, terdapat penanda substitusi nomina 'yang cowok' dan 'yang cewek'. Dua frasa ini mensubstitusi frasa 'orang pacaran' dalam wacana sebelumnya. Frasa 'orang pacaran' dapat dipilah menjadi dua frasa lagi, yaitu yang cowok dan yang cewek. 'Orang pacaran' merupakan frasa yang menduduki kategori nomina. Oleh karena itu, substitusi dengan frasa 'yang cowok' dan 'yang cewek'sepadan karena masih menduduki kategori yang sama.

Terdapat intonasi datar-naik pada wacana 'ngliat orang pacaran pake couple T-Shirt itu geli banget' dan penekanan pada kata 'geli banget'. Tuturan ini disertai dengan mimik wajah comic yang menunjukkan kejijikannya dengan cara seolah-olah seperti orang mau muntah.

(12) j'étais avec une fille jusque y'a pas longtemps, on s'est séparé pareille en fait y'a pas longtemps, parce qu'elle a emménagée avec un autre mec..... alors je l'ai largué ('gue pacaran sama cewek ngga terlalu lama, kita putus juga belum lama, soalnya dia jalan sama cowo lain...trus gue putusin dia deh')

(TS) 
Wacana (12) terdapat satuan lingual «l'»yang merupakan substitusi dari satuan lingual «elle» 'dia' pada wacana sebelumnya. «L'» pada wacana ini merupakan pronomina persona yang menggantikan orang ketiga femina tunggal dari bentuk awal «la». Satuan lingual «la» merupakan pronom objet direct yang digunakan untuk menghindari pengulangan dan pada umumnya ditempatkan sebelum kata kerja. «L'» terbentuk karena diikuti oleh huruf vokal.

\section{Pelesapan/Elipsis}

Pada Istilah linguistik, elipsis merupakan peniadaan kata atau satuan lain yang ujud asalnya dapat diramalkan dari konteks bahasa atau konteks luar bahasa (Kridalaksana, 1983:40). Secara sederhana elipsis merupakan sebuah substitusi zero (ø). Elipsis merupakan sebuah relasi kohesif yang ada di dalam teks di mana satuan lingual yang dilesapkan merupakan satuan lingual yang mengikuti teks. Oleh karena itu, elipsis juga merupakan sebuah relasi yang bersifat anaforis (Halliday, 1975:142-144).

Fungsi pelesapan dalam wacana antara lain (1) menghasilkan kalimat yang efektif, (2) efiensi, yaitu untuk mencapai nilai ekonomis dalam pemakaian bahasa, (3) mencapai aspek kepaduan wacana, (4) bagi pembaca/ pendengar berfungsi untuk mengaktifkan pikirannya terhadap hal-hal yang tidak diungkapkan dalam satuan bahasa, (5) untuk kepraktisan berbahasa terutama dalam berkomunikasi secara lisan.

(13) kamu dong dulu tutup telfonnyaaaa ngga ngga kamu duluuuu ngga ngga kamu dulu kamu dulu!!! (nada galak) ya. Yaudah kamu dulu kamu dulu sama-sama ya satu dua tiga! Kok ngga ditutuuuuupp ø?

(RD)

Pelesapan satuan lingual telefon dalam wacana di atas merupakan elipsis nomina. Pelesapan ini dilakukan karena telfon merupakan informasi lama sehingga tidak perlu disebutkan kembali.

Pada wacana di atas, kata telfon [telfo:n] dan dulu [dulu:] diucapkan panjang pada silaba kedua. Kemudian pada tuturan kamu dulu comic menuturkannya dengan nada galak, seperti orang marah, tetapi seketika setelah itu intonasinya menjadi datar dan menaik pada kata tiga. Setelah itu, kata ditutup juga diucapkan panjang pada silaba ketiga [ditutu:p] dengan intonasi menaik.

14) “Elle m'a dit que j'étais bien chez elle et ø que je pouvais laisser un message après le bip." ("dia bilang sama gue kalo gue itu cocok buat dia dan kalo gue bisa ninggalin pesan abis bunyi bip')

(15) "C'està dire quej'étais capable de la réveiller en plein milieu de la nuit et $ø$ de lui dire ......." ('itu artinya kalo gue bisa ngebangunin dia tengah malem dan ngomong ke dia.....')

Kedua wacana di atas terdapat pelesapan klausa elle m'a dit pada wacana (14) dan klausa j'étais capable pada wacana (15). Pelesapan klausa ini terjadi karena klausa tersebut dianggap sebagai informasi lama sehingga tidak perlu disebutkan kembali dan untuk menghindari adanya pengulangan.

\section{Perangkaian}

Perangkaian di sini berupa konjungsi. Dalam kajian linguistik istilah konjungsi merupakan partikel yang dipergunakan untuk menggabungkan kata dengan frase, klausan dengan klausa, kalimat dengan kalimat, atau paragraf dengan paragraf (Kridalaksana, 1993:117). Konjungsi merupakan salah satu kelompok kata tugas, dengan demikian konjungsi hanya memiliki arti gramatikal, tidak memiliki arti leksikal. Oleh karena itu, makna dari sebuah konjungsi ditntukan berdasarkan kaitannya dengan kata lain dalam frasa atau kalimat (Moeliono, 1998).

Terdapat dua jenis konjungsi yaitu konjungsi koordinatif dan konjungsi subordinatif. Konjungsi koordinatif atau penghubung penghubung yang setara adalah dan, dan lagi, lagi pula, serta, lalu, kemudian, atau, tetapi, tapi, akan tetapi, sedang, sedangkan, namun, melainkan, sebaliknya, bahkan, malah dan malahan, sedangkan dalam bahasa Prancis 
antara lain et, ni, mais, donc, car, or. Konjungsi subordinatif merupakan konjungsi yang menghubungkan klausa inti dan bawahan antara lain bahwa, ketika, sebelum, karena, asal, sekalipun, yang, dan lain-lain sedangkan dalam bahasa Prancis yaitu que, quand, lorseque, bien que, alors que, pour que, afin que, parce que, comme si, etc.

(16) j'étais fou amoureux de cette femme, quand je dis que j'étais fou amoureux

('gue jatuh cinta sama nih cewek ketika gue bilang kalo gue jatuh cinta')

Satuan lingual quand pada wacana di atas menunjukkan keterangan waktu. Quand menggabungkan klausa utama j'étais fou amoureux de cette femme dengan klausa bawahan je dis que j'étais fou amoureux. Wacana (16) comic memberi tekanan lebih pada frasa fou amoureux dan kalimat j'étais fou amoureux, serta comic menuturkan wacana ini dengan nada yang menggebu-gebu.

(17) J'étais avec une fille jusqu'à y'a pas longtemps, on s'est séparépareille en faity'a pas longtemps parcequ'elle est emménagé avec un autre mec. ('gue pacaran sama cewek ngga terlalu lama, kita putus juga belum lama, soalnya dia jalan sama cowo lain')

Pada wacana (17) kata penghubung yang digunakan untuk menciptakan hubungan perangkaian adalah parce que. Kata parce que merupakan konjungsi yang menyatakan hubungan sebab. Pada wacana di atas, klausa yang bermakna sebab adalah elle est emménagé avec un autre mec, sedangkan kalimat yang bermakna akibat adalah on s'est séparé pareille en fait y'a pas longtemps.

(18) gak enak ciuman apalagi ciuman sama kumis

(RD)

Pada wacana (18) terdapat konjungsi apalagi yang menandakan adanya hubungan makna penjumlahan. Klausa ciuman sama kumis merupakan klausa aditif dari klausa sebelumnya yang ditandai oleh kata apalagi. Intonasi pada wacana (18) diucapkan dengan intonasi datar-turun ditambah dengan ekspresi comic yang terlihat jijik disertai gesture comic yang kemudian membalikkan badan.

\section{Kohesi Leksikal}

Kohesi leksikal adalah hubungan leksikal di dalam bagian wacana agar terbentuk suatu keserasian struktur wacana yang kohesif. Kohesi leksikal terdiri dari pengulangan, hiponimi, sinonim, antonimi, dan kolokasi.

\section{Pengulangan}

Pengulangan atau repetisi merupakan jenis kohesi leksikal yang berupa pengulangan satuan lingual tertentu yang dianggap penting untuk memberi tekanan dalam sebuah konteks yang sesuai. Pengulangan satuan lingual dalam sebuah wacana sangat mendukung untuk membangun sebuah wacana yang koheren. Berikut data mengenai repetisi satuan lingual:

(19) Gue jadi rentan galau. Gue rentan galau tiap hari, gue rentan banget sama galau

(20) Ouais sale arabe, sale juif, sale noir ('yaaa, orang-orang arab, yahudi, dan negro yang kotor')

(21) Je commence vraiment à regretter vraiment, parce que vraiment('gue bener-bener deh mulai nyesel beneran deh, karena yaa beneran dehh')

Ketiga wcana stand up comedy di atas terdapat pengulangan/repetisi satuan lingual 'galau', «vraiment» dan «sale». Pengulangan satuan lingual tersebut merupakan penekanan yang diberikan oleh comic dalam mempengaruhi lawan bicara. Misalnya, kata 'galau'yang diulang sebanyak tiga kali dalam wacana bertujuan untuk mempengaruhi lawan bicara bahwa comic sedang dalam kedaan yang 'galau' demikian pula dengan pengulangan satuan lingual « vraiment» yang menunjukkan suatu penekanan untuk meyakinkan lawan tuturnya.

Kemudian, pengulangan kata «sale» pada tuturan «sale arabe, sale juif, et sale noir» memiliki makna yang kasar yaitu 
bedebah. Kata «sale» d untuk mengejek orang-orang Yahudi, Arab dan orang kulit hitam. Ungkapan tersebut sering digunakan oleh remaja Prancis pada umumnya sebagai bahan lelucon rasis.

Ketika comic menuturkan 'gue jadi rentan galau', comic mengucapkan kata galau dengan nada orang yang sedang bersedih tapi tidak disertai senggukan, kemudian intonasi kembali datar pada tuturan gue rentan galau tiap hari hingga pada tuturan gue rentan banget sama galau, kata rentan diucapkan panjang pada silaba kedua [renta:n]. Pengucapan panjang pada kata rentan digunakan sebagai penyangatan akan hati comic yang sedang galau. Tuturan «sale arabe, sale juif, sale noir, super drôle» diucapkan dengan intonasi yang datar dan dengan nada yang melemah karena tuturan tersebut mengandung unsur rasis. Dalam wacana (20) terdapat tiga kali perulangan kata «vraiment», tetapi penekanan atau penyangatan tuturan hanya terdapat pada kata «vraiment» yang pertama saja.

\section{Sinonimi}

Kohesi sinonimi merupakan jenis kohesi leksikal yang berupa relasi makna leksikal yang mirip antara konstituen yang satu dengan yang lain. Adapun Verhaar (1978) mendefinisikan secara semantis bahwa sinonimi adalah alat kohesi yang digunakan sebagai ungkapan (bisa berupa kata, frase, atau kalimat) yang maknananya kurang lebih sama dengan makna ungkapan lain. Sinonimi berfungsi menjalin kepaduan makna dari satuan lingual tertentu dengan satuan lingual yang lain yang memiliki komponen makna sepadan. Oleh karena itu, sinonimi merupakan salah satu piranti kohesi yang mendukung dalam sebuah kepaduan wacana. Berikut contoh sinonimi:

(22) Pedekate juga norak banyak kejijikan yang tersimpan dalam pedekate Yang paling jijik tau ngga apa kalo udah lama telfon-telfonan akan tiba masanya di mana lo akan telfon-telfonan sama gebetan lo dan lo akan main siapa yang akan nutup telfon duluan!!

(RD)
Kata 'norak' dan 'jijik' dalam wacana (22) merupakan kata yang bersinonim dan memiliki kesepadanan makna. Apabila dipertukarkan, wacana tersebut juga masih berterima. Kata 'kejijikan' dalam wacana di atas diucapkan dengan penekanan lebih oleh comic dan pada kata duluan diucapkan dengan nada orang yang sedang marah dengan intonasi yang meninggi.

(22a) Pedekate juga jijik banyak kejijikan yang tersimpan dalam pedekate Yang paling norak tau ngga apa kalo udah lama telfon-telfonan akan tiba masanya di mana lo akan telfon-telfonan sama gebetan lo dan lo akan main siapa yang akan nutup telfon duluan!!

(23) t'sais j'ai peur de m'engager c'est un truc qui me font flipper

('lo tau gue itu takut tunangan, ini itu bikin gue takuut')

Kedua satuan lingual dalam wacana di atas memiliki kesepadanan makna yaitu antara «(avoir) peur» dan «flipper».«Flipper» memiliki arti «(avoir) peur», sehingga kedua verba tersebut dapat dipertukarkan posisinya. Pengucapan tuturan di atas diucapkan dengan intonasi yang datar disertai penekanan pada kata peur.

\section{Antonimi}

Merupakan kohesi leksikal yang berupa relasi makna kontras antara konstituen satu dengan yang lain. Sumarlam (2003:40) menyatakan bahwa antonimi disebut juga dengan oposisi makna. Oposisi makna ini mencakup konsep yang benar-benar berlawanan sampai yang hanya kontras makna saja.

(24) Kamu terlalu baik buat aku, gua harus jawab apa? Gua jawab, maaf sayang aku akan mencoba untuk lebih jahat lagi sama kamu.

Kata yang berantonim pada wacana (24) di atas adalah kata 'baik' dan 'jahat'.'Baik' dan 'jahat' merupakan dua kata yang beroposisi.Tuturan kamu terlalu baik buat aku diucapkan dengan intonasi datar-turun, 
kemudian pada tuturan gua harus jawab apa intonasi datar-naik karena merupakan sebuah tuturan interogatif. Pada tuturan selanjutnya terdapat penekanan pada frasa lebih jahat.

(25) Quand je me réveille je sais pas si c'était un rêve ou la réalité voilà

('ketika gue bangun gue ngga tau itu mimpi atau kenyataan')

Kedua unsur lingual yang dicetak tebal pada wacana (25) merupakan unsur lingual yang berantonim. Unsur yang berantonim yaitu berupa nomina «un rêve» dan «la réalité». Kedua unsur lingual tersebut merupakan perlawanan gradasi yang bersifat kontras.

\section{Kolokasi}

Kolokasi adalah asosiasi tertentu dalam menggunakan pilihan kata yang cenderung digunakan secara berdampingan. Kata-kata yang berkolokasi adalah kata-kata yang cenderung dipakai dalam suatu domain atau jaringan tertentu. Berikut contoh dari kolokasi:

(26) Kerjaan gue ngetweet tiap hari karna gue galau. "Adit angan edih agi...", followerfollower gue bales "cemungud eaaaa Adiiittt.."

Kata-kata yang berkolokasi pada wacana (26) adalah kata 'ngetweet' dan'followerfollower'. 'Tweet'dan 'follower' merupakan satuan lingual yang berada dalam satu domain yang sama yaitu mengenai media sosial twitter, sehingga kedua satuan lingual tersebut merupakan kata yang berkolokasi.

(27) je l'avais invité à une soirée un peu en tête à tête, c'était un dîner aux chandelles ('gue ngundang dia di suatu malam buat candle light dinner')

Kata-kata yang berkolokasi dalam wacana di atas yaitu «une soirée» dan «un dîner aux chandelles». Hal ini dikarenakan «une soirée» dan «un dîner aux chandelles» memiliki relasi makna yang saling berhubungan.

\section{KOHERENSI}

Persyaratan gramatikal dalam wacana dapat dipenuhi kalau dalam wacana sudah terbina kekohesian, yaitu adanya keserasian hubungan antara unsur-unsur yang ada dalam wcana tersebut. Apabila wacana tersebut sudah kohesif, maka terciptalah suatu wacana yang koheren, yaitu isi wacana yang apik dan benar. Singkatnya, piranti kohesi merupakan sebuah alat yang digunakan dalam menunjang wacana menjadi wacana yang utuh. perangkat kohesif hanya digunakan sebagai alat bantu dalam memahami suatu wacana dan menjadi piranti efisien yang memungkinkan pembaca untuk membangun makna sesuai dengan interpretasi pembaca. Dengan kata lain, sejauh kohesi yang ditemukan dalam teks dapat membangun sebuah kekoherensian dalam satu wacana. Pada dasarnya koherensi merupakan suatu rangkaian gagasan yang tersusun secara teratur dan logis. Koherensi juga dapat terjadi secara implisit karena berkaitan dengan makna yang diinterpretasi oleh pembaca/pendengar.

Berbagai macam hubungan antarbagian wacana yang bersifat koheren dapat berupa hubungan sebab-akibat, perurutan, perlawanan, lebih, penjumlahan, waktu, syarat, cara, kegunaan, dan penjelasan. Masing-masing hubungan antarbagian tersebut memiliki penanda koherensi tertentu dalam penunjukan pertalian yang koheren.

\section{Hubungan Makna Penambahan}

(28) Pedekate pedekate juga norak. Mulai ada panggilan-panggilan sayang tau nggak kalo awal-awal lo mulai pedekate itu juga jijik tau ngga lo.

Pada wacana (28) terdapat penanda koherensi yang bersifat aditif yaitu 'juga'. Satuan lingual 'norak' dan 'jijik' merupakan informasi tambahan dan memperkuat alasan mengenai pedekate.

Pada tuturan di atas terdapat jeda setelah kata 'pedekate'. Kemudian terdapat penekanan pada kata 'jijik' yang disertai dengan intonasi meninggi dan nada seperti 
orang yang jijik ketika melihat sesuatu yang tidak ia sukai/menjijikkan.

(29) Moi en plus j'ai sale caractère de merde, t'sais moi chui super têtue, chui un vrai gamin" (SC Tomer Sisley)

('apalagi gue itu punya sifata yang buruk, lo tau gue itu orangnya keras kepala banget, gue itu cowo')

Wacana (29) di atas, koherensi penambahan ditandai dengan adanya satuan lingual «en plus». Satuan «en plus» mempertegas klausa sesudahnya yaitu «j'ai sale caractère de merde». Selain itu, satuan lingual «en plus» juga digunakan untuk mempertegas lagi bahwa comic memang merupakan seorang laki-laki sejati. Tuturan dalam wacana ini diucapkan dengan intonasi yang datar dan tempo yang yang cepat.

\section{Hubungan Makna Pentahapan}

(30) Mulai ada panggilan-panggilan sayang tau nggak kalo awal-awal lo mulai pedekate itu juga jijik tau ngga lo. Mention-mentionan pertama kali kan gitu kan. Lalu punya panggilan sayang

Tampak pada wacana (30) bahwa ada beberapa satuan lingual yang menandai adanya hubungan urutan waktu yaitu 'mulai', 'awal-awal', 'pertama'‘kali' dan'lalu'. Satuan lingual ini menandai bahwa peristiwa tersebut disampaikan secara runtut sesuai dengan urutan waktunya. Dalam tuturan ini comic mengucapkan dengan intonasi yang datar disertai dengan penekanan pada kata jijik untuk menunjukkan penyangatan.

(31) Et puis après on a commencé à se prendre la tête pour le rangement....et puis après ça à commencer à se degrader sexuellemnt elle a commencée à avoir des fantasmes qu'elle voulait qu'on mette en pratique. ('setelah kita berantem masalah kerapian.. kemudian mulai menjurus ke masalah seks, dia mulai punya fantasi-fantasi dan dia pengen nglakuin itu')

Hubungan makna kewaktuan yang terdapat pada wacana (30) ditandai dengan adanya perangkat kohesi yang berupa konjungsi, yaitu konjungsi «et puis après». Konjungsi «et puis après» yang pertama, menggabungkan klausa «on a commencé à se prendre la tête pour le rangement», sedangkan konjungsi «et puis après» menggabungkan klausa «ça à commencer à se degrader sexuellemnt elle a commencée à avoir des fantasmes qu'elle voulait qu'on mette en pratique».

\section{Hubungan Makna Pertentangan}

(32) Kasian orang-orang kayak gue, fakirfakir asmara. Fakir asmara tapi bukan pengemis cinta

Hubungan makna pertentangan pada wacana (32) ditandai dengan satuan lingual 'tapi'. Klausa 'bukan pengemis cinta' merupakan klausa pertentangan dari klausa sebelumnya. Pada tuturan di atas, comic mengucapkan tuturan kasian orang-orang kayak gue dengan intonasi datar-tinggi dan nada seperti orang yang meminta belas kasihan. Selanjutnya pada tutuan fakir asmara, tetapi bukan pengemis cinta diucapkan dengan nada seperti seorang pembaca puisi/romantis.

(33) bon évidemment on était trop différent mais je pense que surtout quand $j^{\prime} y$ réfléchis, surtout on n'avait pas les mêmes peurs dans la vie. Parce que je me souviens une fois je l'avais invité à une soirée un peu en tête à tête, c'était un dîner aux chandelles, c'était vraiment une soirée romantique, à la fin de la soirée je l'ai regardé dans les yeux, je lui ai posé la question "dis-moi qu'est-ce qui te fais le plus peur? " et euh elle m'a dit bah que tu me quittes pour une fille plus jeune que moi et plus belle que moi et que je me retrouve tout seule. Après elle m'a regardée et elle m'a dit "Et toi? Qu'est-ce qui te fais le plus peur?" Alors je lui ai répondu "Les requins... "

('gini yaa, kita itu sebenernya beda banget, terutama nih yaa kita punya ketakutan yang beda banget. gue inget banget pas gue ngajak dia buat makan malam berdua, candle light dinner, itu beneran malam romantis banget. pas udah selesai makan malam, gue nanya sama dia " bilang sama aku, hal apa sih 
yang paling kamu takutin?" dia bilang kalo kamu ninggalin aku buat cewek yang lebih muda dari aku dan yang lebih cantik dari aku dan aku kesepian. Lalu, dia ngliatin gue gitu kan dan dia bilang sama gue " kalo kamu? Apa yang paling kamu takutin?" trus gue jawab "ikan hiu..."'

Pertalian logis dalam wacana (33) merupakan hubungan pertentangan. Hal tersebut dapat diketahui dari klausa «on était trop différent». Hubungan koherensi pertentangan diperjelas lagi dengan adanya klausa "dis-moi qu'est-ce qui te fais le plus peur?" et euh elle m'a dit bah que tu me quittes pour une fille plus jeune que moi et plus belle que moi et que je me retrouve tout seule» yang dipertentangkan dengan klausa " $E t$ toi? Qu'est-ce qui te fais le plus peur?" Alors je lui ai répondu "Les requins..."».

\section{Hubungan Makna Kausalitas}

(34) Gue giliran kan galau. gue mencari-cari pacar baru gitu kan dan gara-gara itu gue jadi gampang kesel. Gue ngeliat yang terjadi sehari-hari, kalo gue liatnya orang pacaran jadi terlihat norak di mata gue.

(RD)

Hubungan kausalitas pada wacana (34) tersebut ditandai dengan adanya konjungsi 'gara-gara itu'. Dalam wacana di atas, klausa 'gue giliran kan galau, gue mencari-cari pacar baru gitu kan' berperan sebagai klausa kausal, sedangkan klausa 'gara-gara itu gue jadi gampang kesel'; kalo gue ngliat orang pacaran jadi terlihat norak di mata gue' berperan sebagai klausa akibat.

(35) pour moi la vraie, vraie vérité pour moi aujourd'hui c'est que j'ai 29 ans bientôt 34 (RIRES) et euh (SILENCE) et la vérité c'est que chui encore célibataire et euh la raison pour ça c'est que euh j'ai...j'ai peur de l'engagement

('buat gue kebenaran itu...kebenaran itu buat gue sekarang ini umur gue 29 taun hampir 34 (KETAWA) dan sebenarnya gue masih jomblo dan karena itu gue... gue takut pacaran')

(TS)
Hubungan makna pada wacana (35) merupakan hubungan makna kausalitas. Hal ini secara eksplisit dapat diketahui dengan adanya klausa «la raison pour ça». Klausa «j'ai peur de l'engagement» merupakan klausa yang menyatakan akibat dari klausa sebelumnya yaitu«chui encore célibataire».

\section{Hubungan Makna Persyaratan}

(36) kalo dia gendut panggilnya enduut bangun dong enduut. Embeeemm,kalo dia tembem kalo dia peyang eyaaaaaang!"

(RD)

Satuan lingual 'kalo' merupakan penanda hubungan makna persyaratan dan pengandaian pada wacana (36). Klausa yang diikuti satuan lingual 'kalo' merupakan klausa yang mengandung persyaratan dan pengandaian. Pengucapan panjang pada 'endut' [endu:t] dan 'embem' [embe:m] pada silaba kedua menunjukkan bahwa 'endut' dan 'embem' merupakan panggilan sayang untuk kekasihnya.

(37) si on peut être sérieux deux minutes, pour moi la vraie, vraie vérité pour moi aujourd'hui c'est que j'ai 29 ans bientôt 34"

('kalo kita bisa serius nih yaa dua menit aja, buat gue kebenaran yang sesungguhnya, itu saat ini umur gue 29 hampir 34 lah yaa')

Hubungan koherensi dinyatakan secara eksplisit dengan konjungsi «si». Klausa «Si on peux être sérieux deux minutes» merupakan syarat terjadinya suatu kejadian di klausa selanjutnya.

\section{SIMPULAN}

Sebuah wacana dikatakan padu apabila mengandung aspek-aspek kohesif yang mendukung kekoherensian wacana. Sama halnya dengan stand up comedy, diperlukan adanya trik-trik khusus agar membuat lawakan menjadi padu dan tidak melompat terlalu jauh dari tema. Trik-trik tersebut yakni perangkat-perangkat kohesi dan koherensi. Perangkat kohesi yang digunakan dalam wacana stand up comedy Prancis 
(Tomer Sisley) dan Indonesia (Raditya Dika) antara lain kohesi gramatikal yang meliputi referensi persona; demonstratif; komparatif, substitusi, elipsis, konjungsi; kemudian kohesi leksikal yang terdiri dari pengulangan, sinonimi, antonimi, dan kolokasi. Selanjutnya piranti koherensi yang digunakan yaitu hubungan makna penambahan, hubungan makna kewaktuan, hubungan makna pertentangan, hubungan makna sebab, hubungan makna akibat, hubungan persyaratan dan pengandaian.

Berdasarkan data yang telah ditemukan, kohesi pengulangan merupakan kekhasan kohesi dalam wacana stand up comedy Prancis maupun Indonesia. Hal ini disebabkan comic berusaha untuk meyakinkan bahkan mempengaruhi penonton bahwa apa yang dikatakan oleh comic memang benar-benar nyata. Selain itu, kohesi pengulangan membuat wacana stand up comedy menjadi satu kesatuan wacana yang koheren.

Selanjutnya ditinjau dari unsur suprasegmentalnya, stand up comedy Indonesia (Raditya Dika) dalam menuturkan wacananya dengan pola intonasi yang variatif, memberikan penekanan yang jelas pada satuan lingual tertentu sebagai bentuk penyangatan, pengucapan panjang pada beberapa satuan lingual pada silaba kedua yang juga sebagai bentuk penyangatan. Tempo dalam penuturan wacana stand up comedy Indonesia, comic menuturkannya dengan tempo yang cukup santai tidak terlalu cepat. Selanjutnya dalam stand up comedy Prancis (Tomer Sisley) comic cenderung mengucapkan wacana stand up dengan tempo yang cenderung cepat, hal ini disebabkan karena gaya bicara orang Prancis yang memang cepat. Intonasinya datarturun tetapi dalam beberapa tuturan comic mengucapkannya dengan intonasi yang menaik.

Analisis kohesi dan koherensi pada data merupakan salah satu dari beberapa aspek stand up comedy yang menarik untuk dikaji. Aspek-aspek lain yang tidak kalah menarik adalah, misalnya, unsur-unsur yang menimbulkan kelucuan yang menjadi ranah pragmatik dan fenomena sosial dalam sudut pandang semiotika sosial.

\section{DAFTAR PUSTAKA}

Almanar, A. E (Penyunting). 2000. Kohesi Dalam Media Massa Cetak Bahasa

Indonesia. Jakarta: Pusat Bahasa Departemen Pendidikan Nasional.

Chaer, Abdul. 1990. Pengantar Semantik Bahasa Indonesia. Jakarta: Rineka Cipta.

Dubois, Jean., \& Lagane, Renê. 1973.La Nouvelle Grammaire du Français. Paris:Larousse.

Halliday, M., \& Hasan, R. 1976. Cohesion In English. London: Longman.

http: / / www.ltml.ci/files/revue / LA \% 20CONSTRUCTION \% 20 SUPRASEGMENTALE \% 20DU\% 20 SENS\%20article\%20fin.pdf diakses pada 9 november 2013 jam 23:19

http:/ / staff.uny.ac.id/ sites/default/files / KOMUNIKASI \% 20 NON \% 20 VERBAL.pdf diakses pada 11 November 2013 jam 15:26

Keraf, G. (1997). Komposisi: Sebuah Pengantar Kemahiran Bahasa. Ende: Nusa Indah.

Kridalaksana, Harimurti. 1983. Kamus Linguistik. Jakarta: Gramedia Pustaka.

Papana, Ramon. 2012. Kiat Tahap Awal Belajar Stand up comedy. Jakarta: Media Kita.

Ramlan. 1987. Sintaksis. Yogyakarta: CV Karyono.

Ramon Papana, 2012, Kiat Tahap Awal Belajar Stand up comedy, Media Kita, Jakarta, hlm. 159)

Widdowson, H.G.2007. Discourse Analysis. New York: Oxford University Press. 